UDC 339.138

\author{
Dovhan Yuriy, \\ Candidate of Economic Sciences, \\ Marketing and Advertising Department, \\ Vinnytsia Institute of Trade and Economics of KNUTE, \\ Vinnytsia; ORCID ID: 0000-0002-0689-7758 \\ e-mail: y.dovhan@vtei.edu.ua
}

https://doi.org/10.29038/2786-4618-2021-03-96-102

\title{
RESOURCES AND TECHNOLOGIES OF THE ENTERPRISE MARKETING MANAGEMENT
}

Introduction. A key feature of the enterprise marketing management is the implementation of management marketing concepts, ideas and approaches in all functional areas of business organization and enterprise management. Marketing management of the enterprise is carried out through the use of resources and marketing technologies.

The purpose of the article. The purpose of the article is to determine the nature, content and features of the use of marketing resources and technologies in the enterprise marketing management.

Results. It is determined that marketing resources should be defined as the means of the enterprise, which allow to form an effective system of creating ideas and goods or services, their pricing, promotion, distribution and help to improve the image of the enterprise and consumer loyalty. Hence, marketing resources are a set of interconnected and interdependent tools that are available and aimed at producing goods and services that have value for consumers and are able to meet their needs at the best price and at the same time make a profit.

It is substantiated that marketing technologies should be considered in a broad sense as a set or model of consistent marketing processes, techniques, actions and a system of scientific knowledge about them, while in a narrower semantic aspect, as a set of marketing tools that are used in the marketing activity of the enterprise. In modern conditions, effective operation of the enterprise involves active use of marketing resources, tools and technologies aimed to achieve social and economic goals of its activities. Marketing tools combined in the marketing technology enable to effectively address issues related to the development, distribution and consumption of goods and services.

Conclusions. Marketing resources and technologies play an important role in the establishment, operation and development of any enterprise. Their competent use enables to improve the level of the enterprise management, increase the competitiveness of the enterprise and its products on the market. Effective market activity and successful competition require that the management of enterprises have knowledge and competencies for the optimal use of marketing resources and use technologies for marketing activities.

Keywords: marketing, management, marketing management, resources, technologies, tools, enterprise.

Довгань Юрій, кандидат економічних наук, кафедра маркетингу та реклами, Вінницький торговельно-економічний інститут КНТЕУ, м. Вінниця

\section{РЕСУРСИ І ТЕХНОЛОГІЇ МАРКЕТИНГОВОГО УПРАВЛІННЯ ПІДПРИЕМСТВОМ}

Маркетингове управління підприємством здійснюється за допомогою використання ресурсів та технологій маркетингу. Визначено, що під ресурсами маркетингу необхідно розуміти засоби підприємства, які дозволяють сформувати ефективну систему створення ідей та товарів або послуг, їх ціноутворення, просування, розподілу та сприяють підвищенню іміджу підприємства та лояльності споживачів. Тобто ресурсами є маркетингу певний комплекс взаємопов'язаних та взаємозалежних засобів, які є в наявності та спрямовані на виробництво саме тих товарів та послуг, які мають цінність для споживачів та здатні задовольняти їхні потреби за оптимальної ціни й одночасно призводять до одержання підприємством прибутку.

Обгрунтовано, що маркетингові технології необхідно розглядати в широкому розумінні, як комплекс або модель послідовних маркетингових процесів, прийомів, дій та система наукових знань про них, а в більш вузькому змістовому аспекті як сукупність інструментів маркетингу, які застосовуються в 
маркетинговій практиці діяльності підприємств. Існує велика кількість різноманітних технологій маркетингу, але всі вони розроблені та використовуються підприємствами 3 метою забезпечення виконання п’яти основних функцій маркетингу: сегментування, таргетування (вибору цільових ринків), позиціонування, аналізу та прогнозування.

Ресурси та технології маркетингу відіграють важливу роль в створенні, функціонуванні та розвитку будь-якого підприємства. Грамотне їх використання дозволяє покращити рівень управління підприємством, підвищити конкурентоспроможність підприємства та його продуктів на ринку. Ефективна ринкова діяльність та успішне ведення конкурентної боротьби потребують від менеджменту підприємств володіння знаннями та компетенціями щодо оптимального використання ресурсів маркетингу та застосування технологій здійснення маркетингової діяльності.

Ключові слова: маркетинг, управління, маркетингове управління, ресурси, технології, інструменти, підприємство.

\section{Довгань Юрий, кандидат экономических наук, кафедра маркетинга и рекламы, Винницкий торгово-экономический институт КНТЭУ,} г. Винница

\section{РЕСУРСЫ И ТЕХНОЛОГИИ МАРКЕТИНГОВОГО УПРАВЛЕНИЯ ПРЕДПРИЯТИЕМ}

Маркетинговое управление предприятием осуществляется посредством использования ресурсов и технологий маркетинга. Определено, что под ресурсами маркетинга необходимо понимать средства предприятия, которые позволяют сформировать эффективную систему создания идей и товаров или услуг, их ценообразование, продвижение, распределение, способствуют повышению имиджа предприятия и лояльности потребителей. Обосновано, что маркетинговые технологии необходимо рассматривать в широком смысле, как комплекс или модель последовательных маркетинговых процессов, приемов, действий и систему научных знаний о них, а в более узком смысловом аспекте как совокупность инструментов маркетинга, которые применяются в маркетинговой практике деятельности предприятий. Эффективная рыночная деятельность и успешное ведение конкурентной борьбы требуют от менеджмента предприятий владения знаниями и компетенциями по оптимальному использованию ресурсов маркетинга и применения технологий осуществления маркетинговой деятельности.

Ключевые слова: маркетинг, управление, маркетинговое управление, ресурсы, технологии, инструменты, предприятие.

Formulation of the problem. In modern market environment that is dynamically changing, the number of market participants increases, competition intensifies, consumer demands for products increase, and therefore the role of marketing in the enterprise management as an effective tool to meet consumer needs and market demands increases significantly. In these conditions, only those companies that implement modern marketing concepts of business organization and marketing approaches to enterprise management can compete successfully. This actualizes the study of the use of resources and technologies of the enterprise marketing management.

Analysis of recent research and publications. Scientific works of such scientists as I. Ansoff, H.L. Bahiiev, J. Boyett, A.V. Voichak, O.I. Gonchar, P. Dixon, P. Doyle, P. Drucker, S.M. Iliashenko, F. Kotler, J.-J. Lamben, M.A. Aucklander, T. Osenton, I.I. Polishchuk, M. Porter, B. Santo and others are devoted to the study of various aspects of the problems of the enterprise marketing management. Despite the importance of the existing scientific achievements, the essence and content of marketing resources and technologies, as well as the issues of their selection and use in the process of marketing management of the enterprise remain insufficiently researched.

The purpose and objectives of the study. The purpose of the article is to determine the nature, content and features of the use of resources and technologies of the enterprise marketing management.

Presentation of the research material. Dynamic development and integration of Ukraine's economy into the world, globalization socio-economic trends increase competition in global and domestic markets, which requires intensification of the market, business, innovation, investment and marketing activities of domestic enterprises.

According to O.I. Gonchar and I.I. Polishchuk, today it is not enough for the management of enterprises to carry out certain marketing activities, but it is necessary to focus on the integrated management of the processes 
of formation and development of marketing potential [1]. In our opinion, the authors are right to argue that competitiveness, profitability, ability to solve socio-economic problems, implementation of requirements for consumer values of goods and services, quality and innovation of products and achievement of strategic goals of the enterprise in modern conditions are possible only through the marketing approach to management, i.e. marketing management.

According to researches [2-5], the main approaches to understanding the essence and content of the category "marketing management", a key feature of which is identified as the implementation of marketing concepts, ideas and approaches in all functional areas of business and enterprise management. The degree of implementation of the marketing management concept depends on the understanding and perception of the marketing enterprise by the top management at the following levels [6]:

1) marketing as a philosophical concept of enterprise management;

2) marketing as a system of organization and management of the enterprise;

3) marketing as a type of the enterprise activity.

The choice of the model of business organization and marketing management of the enterprise depends on the level of perception of the marketing concept. Marketing models of business organization and marketing management can be grouped into three main types.

The model of "production orientation" involves management of the enterprise on the basis of previously created production facilities and technologies, as well as assumptions about the market need for products that were previously produced with the help of existing production facilities and technologies. Under the conditions of application of the model of "sales orientation" the company retains a previously formed production orientation, but begins to partially use traditional marketing resources, technologies and management tools. According to the model of "market orientation", management of the enterprise is based on the needs and desires of consumers, which are regarded as market opportunities. Under this model, the company tries to make the most of traditional and innovative marketing resources and management technologies.

The choice of a model of the enterprise marketing management depends on many factors, one of the key among which are marketing resources, opportunities and competencies of the enterprise for their implementation, i.e. marketing potential of the enterprise. In the modern economic literature there are many different definitions of the concept of "enterprise potential", but in the broadest sense scientists $[1 ; 7 ; 8]$ offer to define the potential of the enterprise as the resources (funds, stocks, sources) of the enterprise, which are available and which can be mobilized, put into action, used to achieve a certain goal, implement a plan, solve a problem of the enterprise.

Potential of the enterprise has two key components:

- objective (production, land, technological, personnel, financial potential as well as fixed and current assets);

- subjective (logistics, management, marketing potential and potential of the organizational structure).

General and marketing potentials of the enterprise include:

1. Technical resources.

2. Energy resources.

3. Technological resources.

4. Human resources.

5. Spatial resources.

6. Resources of the organizational structure of the management system.

7. Information resources.

8. Financial resources.

An indisputable approach in the process of forming and developing the overall potential of the enterprise is the focus on market research as well as on the formation and management of marketing potential of the enterprise [9]. Formation and implementation of the marketing potential of the enterprise through marketing management significantly affect the effectiveness of the enterprise.

This influence is manifested in three main effective areas [9, p. 48]:

1) making a profit;

2) development of effective marketing concepts of goods and services;

3 ) the impact on the characteristics of consumer attitudes to the enterprise.

If the profit is the result of joint efforts of all departments in all areas of the enterprise, the effectiveness of the second and third areas depends solely on the effective use of marketing resources and technologies of the enterprise management.

In the modern scientific literature on the problems of marketing management, the terms "marketing resources" or "marketing resources", "marketing technologies" or "marketing technologies" are widely used.

Marketing resources are defined as the means of the enterprise, which enables to form an effective system of creating ideas and goods or services, their pricing, promotion, distribution and help to improve the image of the enterprise and consumer loyalty. Hence, marketing resources are a set of interconnected and interdependent 
tools that are available and aimed at producing those goods and/or services that have value for consumers and are able to meet their needs and/or demands at the best price and at the same time lead to obtaining long-term profit by the manufacturer or provider of relevant services. Marketing resources are classified as follows [10, $\mathrm{p}$. 141]:

- material marketing resources (resources that can be identified in physical units): scientific and methodological bases (borrowed knowledge and experience), special computer programs;

- intangible marketing resources (resources that are available, but they are intangible): development strategies and programs for their implementation, a formed customer base of consumers and partners, the portfolio of orders, market position, a formed image.

Marketing technologies are defined by scientists as a set or model of interconnected marketing entities, management procedures, certain processes and their stages, clear in their sequence of operations, techniques and actions aimed at achieving marketing goals; system of scientific knowledge on the formation of the relevant stages, a list of specific operations, techniques and actions implemented by specialists in the field of marketing; a set of social and managerial processes aimed at meeting the needs of consumers; methods that are aimed at the successful operation of the enterprise in the market.

Thus, marketing technologies are considered in a broad sense as a set or model of consistent marketing processes, techniques, actions and a system of scientific knowledge about them. In a narrower semantic aspect, scientists focus on the subject of research and identify specific marketing technologies that have already formed in theory and are used in the practice of marketing activities of enterprises.

Marketing technologies are considered from the following positions:

- theoretical position (special area of knowledge about the ways and procedures of optimization of marketing processes in the conditions of growing interdependence, dynamics and restoration of social and economic processes);

- methodical position (method of realization of marketing actions on the basis of separate marketing procedures and operations with their further coordination and synchronization and a choice of optimum means, tools and methods of their performance);

- management position (a method of managing marketing processes, which provides a system of their reproduction in certain parameters of quality, properties, volume, integrity of activity, etc.).

Therefore, marketing technology is a set of measures, methods of action and decision-making, which determines the activities of the enterprise aimed to manage its position in the market, select and achieve its main goals by implementing management functions of planning, organizing, analyzing and monitoring market results, investigation of its competitors and market situation.

It should be noted that the processes of using marketing resources and technologies consist of certain sequences of interconnected stages, but these sequences are not always the same, because marketing combines the elements of practice, science and art of marketing, i.e. creativity.

Before developing a marketing mix and choosing specific resources, tools and technologies of marketing, the company must determine the overall competitive and marketing strategy. The process of forming a marketing strategy logically begins with the analysis of external and internal environment of the enterprise on the basis of information obtained as a result of marketing research and interpreted through the use of tools of the marketing information system.

Formation of marketing strategies and tactics of the enterprise, the choice of resources and technologies of marketing are to be carried out only after formation of the enterprise purposes in all spheres of its activity, estimation of strategic alternatives and the choice of marketing strategies and tactics. It is mandatory to organize feedback at the stages of analysis of strategic alternatives and implementation of technologies, tactics and strategies. The stage of evaluation of results, control and motivation of technology implementation should not be final, but act as an intermediate stage and source of information formation for subsequent steps in the continuous process of formation and adjustment of marketing technologies, tactics and strategy of the enterprise.

There are many different marketing technologies, but they are all designed and used by the companies to ensure five main functions of marketing: segmentation, targeting (selection of the target markets), positioning, analysis and forecasting.

Traditional marketing resources and technologies are no longer as effective as they used to be. Therefore, F. Kotler proposes to revise and supplement them, applying elements of new marketing approaches to business management [11, p. 13-14], namely to focus on the values that exist throughout the whole life of consumers; to evaluate of results both by marketing and financial indicators; to focus on the satisfaction of several groups of stakeholders; to carry out on-going marketing management of the enterprise; to form brands due to the activities of all divisions of the enterprise; to focus on consumer retention; to carry out value chain analysis.

The use of resources and marketing technologies should ensure the success of the enterprise due to higher product quality; more complete customer service; lower prices; higher market share; mass production fort the order; continuous product improvement; product innovation; dynamic growth of markets; exceeding of consumer expectations. 
According to T. Ossenton, integrated use of tools of both mass and individual marketing are the main factors of successful use of resources and technologies of marketing in the modern information economy. Thus, the researcher identifies ten main marketing trends [12, p. 292-294]:

1. Decrease in the number of resellers in both traditional and interactive environments.

2. Increase in the number of manufacturers who directly sell their products with tools and technologies of ecommerce, direct individual marketing, etc.

3. Increase in the number of partner companies for the joint sale of goods in the Internet.

4. Reduction of the number of printed trade catalogs, increase in the number of interactive catalogs.

5. Increase in the number of enterprises that resort to consumer authorization.

6. Higher attention to the protection of privacy not only on the Internet, but also in other means of communication.

7. Increase in the number of marketers who practice marketing of the share of consumption.

8. Increase in the volume of collection and analysis of consumer information by electronic means. Therefore, companies use the Internet for their own research, often through focus groups with consumers. Moreover, the facts (what the consumer did or did not do) and explanations (why the consumer did or did not do) are investigated.

9. Increase in the volume of electronic messages, continuous improvement of the quality and volume of digital information.

10. Association of advertisers with information technology specialists in order to spread advertising in places of the highest concentration of consumers.

Marketing researcher J. Boyet has identified five factors of success in the use of marketing resources and technologies that cannot be provided within traditional marketing [13, p. 65]:

- more supply - less differentiation;

- more global - less local;

- more competition - more interaction;

- more interaction - less transactions;

- more comprehension and response - less situation "produced and sold".

The use of marketing resources and technologies can increase management efficiency and contributes to:

- rational use and specialization of managerial work;

- constant control, which allows to detect, prevent and eliminate deviations at all stages of activity;

- determination and distribution of typical and creative management procedures;

- development of effective methods for solving management problems;

- adaptation of scientific methods and management tools.

Specific features of the use of marketing resources and technologies in the management of enterprises in modern conditions [14] are as follows:

- development for specific purposes of the market activity of the enterprise;

- low guarantee of achieving the final result due to the contradictions and uniqueness of their object;

- individuality, which is associated with the fact that the development and implementation of specific marketing technologies changes the system of formal and informal relations between people, restructures the structure of rights and responsibilities, the relationship of real power at the enterprise;

- focus on strategic goals of the enterprise development;

- integration with the general management system;

- complexity;

- scientific validity;

- continuity and systematic updating;

- maintaining the dynamics of implementation;

- adaptability, etc.

It should be noted that the formation and implementation of management policy of the enterprise must be carried out comprehensively and within the general competition policy, i.e. the choice of specific resources and marketing technologies should be carried out in accordance with the overall strategy and tactics of enterprise management.

Conclusions and prospects for further research. In modern conditions, effective operation of the enterprise involves active use of marketing resources, tools and technologies to achieve social and economic goals of its activities. Marketing tools combined in marketing technology enable to effectively address issues related to the development, distribution and consumption of goods and services.

Marketing resources and technologies play an important role in the establishment, operation and development of any enterprise. Their competent use enables to improve the level of the enterprise management, increase competitiveness of the enterprise and its products on the market. Effective market activity and successful competition require that the management of enterprises have knowledge and competencies for the optimal use of marketing resources and use technologies for marketing activities. 
Further research is needed on the selection and practical use of marketing resources, tools and management technologies, a rational combination of traditional marketing technologies with their advanced versions and the latest advances in the field of information technologies, which will allow Ukrainian companies to increase the level and efficiency of marketing management in modern business conditions.

\section{References}

1. Honchar O. I., Polishchuk I. I. (2019). Intehratsiini faktory suchasnosti yak peredumovy rozvytku marketynhovoho potentsialu [Integration factors of modernity as prerequisites for the development of marketing potential]. Zhurnal yevropeiskoi ekonomiky. 18. 2 (69). 154-166 [in Ukrainian].

2. Dovhan Yu. V. (2020). Formuvannia marketynhovoi stratehii prosuvannia innovatsiinykh roslynnykh kharchovykh olii [Formation of a marketing strategy for the promotion of innovative vegetable edible oils]. Ekonomika ta derzhava. 1. 126-131. Doi: 10.32702/2306-6806.2020.1.126 [in Ukrainian].

3. Polishchuk I. I., Dovhan Yu. V. (2020). Marketynhovi aspekty upravlinnia oliino-zhyrovymy pidpryiemstvamy. [Marketing aspects of management of oil and fat enterprises]. Visnyk Khersonskoho natsionalnoho tekhnichnoho universytetu. 2 (73). 93-100. doi: 10.35546/kntu2078-4481.2020.2.12 [in Ukrainian].

4. Dovhan Y. (2020). Innovation and Investment Activity of the Oil and Fat Enterprises as an Object of Marketing Management. Modern paradigms in the development of the National and World economy : The materials of the International Scientific Conference. October, 30-31, 2020. Chișinău : Universitatea de Stat din Moldova. Chișinău, 267-273 [in English].

5. Gonchar O., Zamkova N., Polishchuk I., Dovhan Y., Sokolovska V. (2020). Oil and Fat Business of Ukraine: Marketing Orientation for Achieving Competitive Advantages. European Journal of Sustainable Development. 9. 4. 261-272. doi: 10.14207/ejsd.2020.v9n4p261 [in English].

6. Doil P. (2001). Marketing, orientirovannyj na stoimost' [Value-oriented marketing]. Sankt-Peterburg : Piter, 480 [in Russian].

7. Honchar O. I. (2009). Evoliutsiia katehorii «Potentsial pidpryiemstva» ta yii rol v ekonomichnykh doslidzhenniakh [Evolution of the category «Enterprise potential» and its role in economic research]. Retrieved from : http://archive.nbuv.gov.ua/portal/natural/Vchnu/ekon/2009_5_3/245-247.pdf [in Ukrainian].

8. Polishchuk I. I. (2017). Mizhnarodna intehratsiia i rozvytok marketynhovoho potentsialu promyslovykh pidpryiemstv [International integration and development of marketing potential of industrial enterprises]. Naukovyi visnyk Poltavskoho universytetu ekonomiky i torhivli. 4 (82). 152-158 [in Ukrainian].

9. Potrashkova L. V. (2015). Otsiniuvannia marketynhovoi diialnosti pidpryiemstva za kryteriiem stvorennia maibutnikh spromozhnostei do formuvannia popytu [Evaluation of marketing activities of the enterprise by the criterion of creating future capabilities to form demand]. Marketynh $i$ menedzhment innovatsii. 3. 47-55 [in Ukrainian].

10. Bilovodska O. A., Kovalenko Ya. A. (2014). Teoretychni zasady otsinky marketynhovykh resursiv pry zabezpechenni innovatsiinoho rozvytku pidpryiemstv ta rehionu [Theoretical bases of an estimation of marketing resources at maintenance of innovative development of the enterprises and region]. Visnyk Donbaskoi derzhavnoi mashynobudivnoi akademii. 2 (33). 138-141 [in Ukrainian].

11. Kotler F., Tryas de Bez F. (2004). Novye marketingovye tekhnologii. Metodiki sozdaniya genial'nyh idej [New marketing technologies. Techniques for creating brilliant ideas]. St. Petersburg : Neva, 192 [in Russian].

12. Osenton T. (2003). Novye tekhnologii v marketinge: zolotoj klyuchik k loyal'nosti potrebitelej [New technologies in marketing: the golden key to consumer loyalty]. Moskva : Vil'yams, 304. [in Russian].

13. Bojett Dzh. (2004). Guru marketinga. Kakim byt' marketingu v tret'em tysyacheletii [Marketing guru. What to be marketing in the third millennium]. Moskva : Eksmo, 320 [in Russian].

14. Zorina O. I., Mkrtychian O. M. (2017). Suchasni marketynhovi tekhnolohii ta yikh spetsyfika [Modern marketing technologies and their specifics]. Mizhnarodnyi naukovyi zhurnal «Internauka». Ekonomichni nauky. 9 (31). 49-51 [in Ukrainian].

\section{Джерела та література}

1. Гончар О. I., Поліщук I. I. Інтеграційні фактори сучасності як передумови розвитку маркетингового потенціалу. Журнал європейської економіки. 2019. Том 18. № 2 (69). С. 154-166.

2. Довгань Ю. В. Формування маркетингової стратегії просування інноваційних рослинних харчових олій. Економіка та держава. 2020. № 1. С. 126-131. Doi: 10.32702/2306-6806.2020.1.126.

3. Поліщук І. І., Довгань Ю. В. Маркетингові аспекти управління олійно-жировими підприємствами. Вісник Херсонського національного технічного університету. 2020. № 2 (73). С. 93-100. doi: 10.35546/kntu2078-4481.2020.2.12.

4. Dovhan Y. Innovation and Investment Activity of the Oil and Fat Enterprises as an Object of Marketing 
Management. Modern paradigms in the development of the National and World economy: The materials of the International Scientific Conference. October, 30-31, 2020. Chișinău : Universitatea de Stat din Moldova. Chișinău, 2020. P. 267-273. https://ibn.idsi.md/sites/default/files/imag_file/267-273_8.pdf

5. Gonchar O., Zamkova N., Polishchuk I., Dovhan Y., Sokolovska V. Oil and Fat Business of Ukraine: Marketing Orientation for Achieving Competitive Advantages. European Journal of Sustainable Development. 2020. Vol. 9. № 4. P. 261-272. doi: 10.14207/ejsd.2020.v9n4p261.

6. Дойль П. Маркетинг, ориентированный на стоимость / пер. с англ. Санкт-Петербург : Питер, 2001. $480 \mathrm{c}$.

7. Гончар О. І. Еволюція категорії «Потенціал підприємства» та її роль в економічних дослідженнях. Режим доступу : http : //archive.nbuv.gov.ua/portal/natural/Vchnu/ekon/2009_5_3/245-247.pdf

8. Поліщук I. I. Міжнародна інтеграція і розвиток маркетингового потенціалу промислових підприємств. Науковий вісник Полтавського університету економіки і торгівлі. 2017. № 4 (82). С. 152158.

9. Потрашкова Л. В. Оцінювання маркетингової діяльності підприємства за критерієм створення майбутніх спроможностей до формування попиту. Маркетинг і менеджмент інновацій. 2015. № 3. С. 47 55.

10. Біловодська О. А., Коваленко Я. А. Теоретичні засади оцінки маркетингових ресурсів при забезпеченні інноваційного розвитку підприємств та регіону. Вісник Донбаської державної машинобудівної академії. 2014. № 2 (33). С. 138-141.

11. Котлер Ф., Триас де Без Ф. Новые маркетинговые технологии. Методики создания гениальных идей / пер. с англ. Санкт-Петербург : Нева, 2004. 192 с.

12. Осентон Т. Новые технологии в маркетинге: золотой ключик к лояльности потребителей / пер. с англ. Москва : Вильямс, 2003. 304 с.

13. Бойетт Дж. Гуру маркетинга. Каким быть маркетингу в третьем тысячелетии / пер. с англ. Москва : Эксмо, 2004. 320 с.

14. Зоріна О. І., Мкртичьян О. М. Сучасні маркетингові технології та їх специфіка. Міжнародний науковий журнал «Інтернаука». Економічні науки. 2017. № 9 (31). С. 49-51.

Стаття надійшла до редакції 19.08.2021р. 